\title{
Modulation of gregarious settlement of the stalked barnacle, Pollicipes pollicipes: a laboratory study
}

\author{
Sofia C. Franco ${ }^{1,2}$, Nick Aldred ${ }^{1}$, Teresa Cruz ${ }^{2,3}$, Anthony S. Clare ${ }^{1}$ \\ ${ }^{1}$ School of Marine Science and Technology, Newcastle University, Newcastle Upon Tyne, United Kingdom. \\ E-mail: sofia.cota-franco@newcastle.ac.uk \\ ${ }^{2}$ Departamento de Biologia, Escola de Ciências e Tecnologia, Universidade de Évora, Portugal. \\ ${ }^{3}$ MARE-Marine and Environmental Sciences Centre, Laboratório de Ciências do Mar, Universidade de Évora, \\ Apartado 190, 7521-903 Sines, Portugal.
}

\begin{abstract}
Summary: Although recruitment patterns of Pollicipes pollicipes (Crustacea: Scalpelliformes) in the wild have been investigated, no studies have yet focused on the factors that affect settlement. In the present paper, settlement of $P$. pollicipes on conspecifics (gregarious settlement) was investigated in the laboratory as a function of environmental conditions (hydrodynamics, temperature, light and salinity), larval age and batch. This study aimed to understand how these factors modulate settlement in the laboratory and elucidate how they might impact recruitment patterns in nature. Maximum attachment on adults was $30-35 \%$, with a one-week metamorphosis rate of 70-80\%. Batch differences affected both attachment and metamorphosis. Attachment rate was higher at natural salinity (30-40 psu), with lower salinity (20 psu) decreasing metamorphosis rate. Cyprid attachment was stimulated by light conditions and circulating water. This might relate to a preference for positioning high in the water column in nature, but also to increased cyprid-surface contact in conditions of circulating water. Older cyprids ( 3 or 6 days) showed higher attachment than un-aged larvae, though fewer 6-day-old larvae metamorphosed. Temperature did not affect attachment rate, but the metamorphosis rate decreased at $14^{\circ} \mathrm{C}$ (compared with 17 or $20^{\circ} \mathrm{C}$ ), implying that differences in temperature during the breeding season can affect how quickly cyprids metamorphose to the juvenile. Cyprids survived for prolonged periods ( $\geq 20$ days; $40 \%$ survival), likely due to efficient energy saving by intercalating long periods of inactivity with fast bursts of activity upon stimulation.
\end{abstract}

Keywords: stalked barnacles; larva; settlement; attachment; metamorphosis; cyprids; aquaculture.

Modulación del asentamiento gregario del percebe, Pollicipes pollicipes: un estudio de laboratorio

Resumen: Aunque se han investigado los patrones de reclutamiento de Pollicipes pollicipes (Crustacea: Scalpelliformes) en la naturaleza, actualmente no existen estudios sobre los factores que afectan al asentamiento larval. En el presente trabajo, el asentamiento de larvas de $P$. pollicipes sobre adultos conspecíficos (asentamiento gregario) fue investigado en el laboratorio en función de las variables ambientales (hidrodinamismo, temperatura, luz y salinidad), la edad y los distintos lotes de larvas. Este estudio tuvo como objetivo comprender cómo estos factores afectaban al asentamiento en el laboratorio y elucidar el modo en que podrían afectar a los patrones de reclutamiento en el medio natural. La fijación máxima en adultos fue de $30-35 \%$, con una tasa de metamorfosis de 70 a $80 \%$ en una semana. Las tasas de fijación y de metamorfosis variaron dependiendo de los distintos lotes de larvas. La tasa de fijación fue superior cuando la salinidad era la natural (30-40 psu), mientras que la tasa de metamorfosis disminuía cuando la salinidad era inferior ( $20 \mathrm{psu}$ ). La fijación de la larva cipris se estimulaba en condiciones de luz y agua circulante, lo que puede estar relacionado con la preferencia por el posicionamiento de la larva cipris en lo alto de la columna de agua en el medio natural, y además, también con un mayor contacto entre la larva cipris con las superficies en condiciones de agua circulante. Las larvas cipris de más edad (de 3 a 6 días) tuvieron una fijación más alta que las de menor edad, aunque luego, menos larvas de 6 días de edad metamorfosearan. La temperatura no afectó a la tasa de fijación, pero sí se reducía la tasa de metamorfosis a $14^{\circ} \mathrm{C}$ (en comparación con 17 o $20^{\circ} \mathrm{C}$ ), lo que implica que las diferencias en la temperatura durante el período de reproducción pueden afectar a la rapidez de la metamorfosis de las larvas cipris a juveniles. Las larvas cipris sobrevivieron periodos de tiempo prolongados ( $\geq 20$ días; con un $40 \%$ de supervivencia), probablemente debido a una capacidad de conservación de energía eficiente, intercalando largos períodos de inactividad con movimientos repentinos y actividad cuando eran estimuladas.

Palabras clave: percebes; larvas; asentamiento; fijación; metamorfosis; larva cipris; acuicultura.

Citation/Como citar este artículo: Franco S.C., Aldred N., Cruz T., Clare A.S. 2016. Modulation of gregarious settlement of the stalked barnacle, Pollicipes pollicipes: a laboratory study. Sci. Mar. 80(2): 217-228. doi: http://dx.doi.org/10.3989/ scimar.04342.01A

Editor: X. Turon.

Received: August 31, 2015. Accepted: April 4, 2016. Published: June 3, 2016.

Copyright: () 2016 CSIC. This is an open-access article distributed under the Creative Commons Attribution-Non Commercial Lisence (by-nc) Spain 3.0. 


\section{INTRODUCTION}

Harvesting Pollicipes pollicipes is an economically important activity in Portugal and Spain, where this species is subject to an intensive fishery (Molares and Freire 2003, Borja et al. 2006, Sousa et al. 2013). Due to its high market value, conservation interest and stock management concerns, there has been continued interest in the reproductive cycle and recruitment patterns of this species.

$P$. pollicipes is a pedunculate barnacle, abundant in the very exposed mid- and low-intertidal rocky shore (Barnes 1996, Cruz et al. 2010), normally found in clusters of sessile adults and juveniles attached to each other and to the primary rock substratum. These simultaneous hermaphrodites and obligate cross-fertilizers require gregariousness in order to mate with conspecifics (Molares et al. 1994, Pavón 2003). After mating, embryonic development occurs and hatched larvae are released into the water column, where they moult successively until the non-feeding cypris stage, which is responsible for surface selection and settlement (Molares et al. 2002). In the wild, the ability of barnacle cyprids to find a place to attach permanently depends on larval survival and transport, as well as larval selectivity (Shanks 1986, Bertness et al. 1996).

The cyprid of $P$. pollicipes settles (in this paper, settlement comprises both attachment and metamorphosis) intensively on adults of the same species or on substrata that have been in contact with conspecific adults (e.g. Kugele and Yule 1996, Cruz et al. 2010). The cyprid explores surfaces prior to settlement using a mechanism of temporary adhesion, which allows it to probe a surface's physical and chemical characteristics before attaching permanently (Aldred and Clare 2009). Cyprids can postpone their settlement (Krug 2006) in order to select a substratum that is suitable, possibly exploring surfaces and returning to the water column repeatedly before committing to permanent attachment. Once the attachment site has been selected, the cyprid secretes a second adhesive that permanently fixes it to the substratum (e.g. Nott and Foster 1969, Walker 1971, Aldred et al. 2013). Immediately after attachment, the cyprid begins metamorphosis into the juvenile barnacle.

Settlement is difficult to estimate in the wild and studies often report recruitment, referring to the product of successful settlement followed by a period of postsettlement survival. Consequently, although previous field studies have allowed for a better understanding of recruitment of this species (e.g. Cruz et al. 2010), little is known about the environmental and cyprid-related factors that affect settlement, including the process of substratum selection.

Unlike $P$. pollicipes, a few barnacle species such as Balanus amphitrite (=Amphibalanus amphitrite) have been the target of extensive research stemming in part from their importance as fouling organisms. Barnacle settlement is known to be influenced by surface physical characteristics (e.g. Crisp and Barnes 1954, Le Tourneux and Bourget 1988), available space (e.g. Minchinton and Scheibling 1993), chemical signals and cues (e.g. Clare et al. 1995, Holm et al. 2000) and allospecific interactions (e.g. presence and characteristics of biofilms; Maki et al. 1988, Keough and Raimondi 1996, Wieczorek and Todd 1998). Natural cuticle-bound chemical signals produced by adult barnacles in the form of the settlement-inducing protein complex, or left on surfaces by conspecific cyprids as footprints (e.g. Matsumura et al. 1998, 2000, Dreanno et al. 2006), also act as attractants to exploring barnacle cyprids.

Studies with other barnacle species have further highlighted the importance of environmental factors, such as hydrodynamics, temperature, salinity and light in settlement modulation. Evidence from laboratory studies with Balanus amphitrite, Elminius modestus (=Austrominius modestus) and Semibalanus balanoides (=Balanus balanoides) suggest that settlement behaviour and surface rejection can vary according to flow and water speed (Crisp 1955, Mullineaux and Butman 1991, Rittschof et al. 1984). Both temperature and salinity influence settlement, with effects varying according to species (e.g. Dineen and Hines 1992, Marechal et al. 2004) and often within wide ranges (e.g. B. amphitrite settles from 15 to $37^{\circ} \mathrm{C}$, with a maximum at 25 to $28^{\circ} \mathrm{C}$, and $14-52 \mathrm{psu}$, with a peak settlement at 28-35 psu; Kon-Ya and Miki 1994). Similarly, barnacle settlement is affected by different light conditions (Crisp and Ritz 1973, Pawlik 1992, Kon-Ya and Miki 1994).

Cyprid-related factors, such as larval origin, genetic background, parental effects (Holm et al. 2000, Holm 2012), cyprid condition (Thiyagarajan et al. 2002) and age (Holm et al. 2000, Marechal et al. 2012) have also been shown to impact settlement. The effects of age, in particular, have been reported for various species (e.g. B. amphitrite, B. improvisus, B. subalbidus, $B$. eburneus), with cyprid selectivity decreasing with increasing age and cyprids losing the ability to metamorphose after a certain age (Dineen and Hines 1992, Thiyagarajan et al. 2002, Marechal et al. 2004).

Studies on the settlement of $P$. pollicipes in culture are extremely limited (e.g. Coelho 1991, Kugele and Yule 1996), due to both the reportedly high cyprid selectivity when settling on artificial substrata and the difficulty of rearing viable larvae in the laboratory (e.g. Coelho 1990, Molares et al. 1994). This constitutes a considerable research gap in understanding the relative importance of the aforementioned factors in modulating recruitment in nature and in developing the culture of this species. The few laboratory studies with $P$. pollicipes habitually used artificial substrata under static conditions and standard temperature and salinity, with no reference to other culture factors (e.g. light, cyprid age) and with reports of either null or negligible settlement (Coelho 1991, Molares 1994, Kugele and Yule 1996). The best results, with $<1 \%$ of settlement, were attained by Kugele and Yule (1996), who reported that the limited settlement occurred mostly on the adults $(\approx 93 \%$ of the 115 settled larvae) rather than on artificial substrata. Nevertheless, though the lack of settlement on artificial substrata in culture prevents the use of standard laboratory assays, the strong preference for 
settlement on conspecific adults presents an opportunity to understand the key environmental and larvalrelated factors that modulate settlement of the species.

To this end, the present study investigated the effects of environmental conditions (hydrodynamics, temperature, salinity and light) and cyprid-related factors (cyprid age and batch) on the settlement of $P$. pollicipes on conspecifics, in order to better understand the effects of these factors on laboratory settlement and, by extension, on natural recruitment. It was hypothesized that attachment would be higher under conditions observed during the breeding season (e.g. higher temperature and a long-day photoperiod), decreasing with unnatural salinities (e.g. 20 psu), with hydrodynamic conditions (e.g static) and in older cyprids, and varying with batch. It was further hypothesized that metamorphosis would vary with environmental factors, age and batch due, respectively, to the possible impact of these factors on metabolism, energy reserves and parental/ genetic effects. Furthermore, temporal patterns of settlement were investigated to determine the attachment and metamorphosis rate, as well as the survival of cyprids in culture.

\section{MATERIALS AND METHODS}

\section{Barnacle collection and larval culture}

Clusters of barnacles were collected from the SW coast of Portugal (Cabo Sardão, Portugal, $37^{\circ} 36^{\prime} 24.70^{\prime \prime} \mathrm{N}, 8^{\circ} 49^{\prime} 2.00^{\prime \prime} \mathrm{W}$ ) during the reproductive season and transported within $36 \mathrm{~h}$ to the School of Marine Science of Technology (Newcastle University, UK), where the barnacles were dissected ( $\mathrm{n} \geq 60$ individuals) to extract egg lamellae. Lamellae were separated according to developmental stage and mature lamellae were cut to assist naupliar release. Nauplii were selected by positive phototaxic behaviour and transferred into culture. Cultures were semistatic, with minimal bottom aeration, in plastic carboys containing $10 \mathrm{~L}$ of $0.2 \mu \mathrm{m}$ natural filtered seawater (FSW) at $20 \pm 1^{\circ} \mathrm{C}, 16: 8 \mathrm{~L} / \mathrm{D}$ (dim light, 200-1500 lux), 33 \pm 1 psu and antibiotics $\left(0.0232 \mathrm{~g} \mathrm{l}^{-1}\right.$ penicillin and $0.0369 \mathrm{~g} \mathrm{l}^{-1}$ streptomycin), with 1 larva $\mathrm{ml}^{-1}$. Cultures were fed after water changes every two days with a 1:1 mixed diet of Tetraselmis chuii and Isochrysis galbana $\left(10^{4}\right.$ cells $\mathrm{ml}^{-1}$ ). Larval cultures were monitored daily in order to determine when the majority had reached the cyprid stage, whereupon cultures were filtered through a 60$\mu \mathrm{m}$ mesh.

\section{Experimental design and data collection}

A series of six experiments (Exp. 1 to 6) were conducted to test the factors that mediate cyprid settlement on adults and to investigate the effects of abiotic and biotic factors on attachment and metamorphosis. These included testing various environmental conditions, specifically hydrodynamics (Exp. 1; August 2012), temperature (Exp. 2; June 2012), salinity (Exp. 3; June 2013) and light (Exp. 4; August 2013), as well as cyprid age (Exp. 5; August 2011) and batch (Exp. 6;

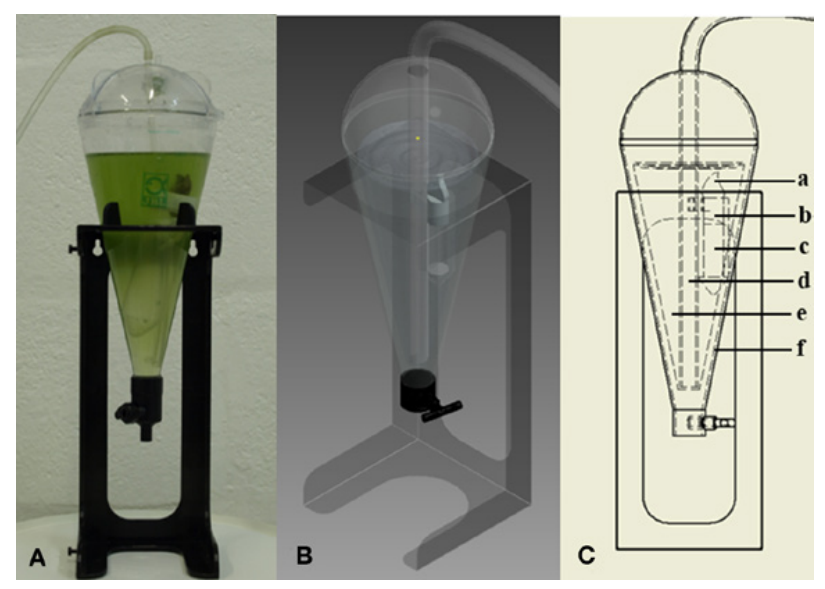

Fig. 1. - Photograph (A), simplified CAD model (B) (rotated view) and annotated diagram (C) of the standard experimental setup used, where $a$, is adult barnacle capitulum; $b$, adult barnacle stalk; $c$, tube with cyprids and adult stalk in seawater; $d$, airline; e, surrounding seawater; and f, conical flask. The setup consists of a 500-ml conical flask containing seawater, which holds internally a vertically placed 50 -ml tube (whose lid has been cut off) containing an adult barnacle (held vertically by the Parafilm used to seal the tube), whose capitulum extends towards the outside and the stalk towards the inside of the tube. The inner tube contained both the adult barnacle stalk and cyprids, while on the outside of the tube the barnacle could extend the cirri and feed on microalgae without the risk of cannibalism.

June 2011, 2012, 2013). Two additional experiments (Exp. 7 and 8; respectively done in August 2011 and 2012) were conducted to follow cyprid settlement (attachment and metamorphosis) and survival over time. Identical assays were conducted for all experiments with the setup adjusted for the factor under investigation, as detailed below. Cyprid settlement assays were no-choice assays (except Exp. 4) in 500-ml conical flasks, $0.2 \mu \mathrm{m}$ natural FSW, kept at $20 \pm 1^{\circ} \mathrm{C}, 16: 8 \mathrm{~L} / \mathrm{D}$ (dim light, 500-1000 lux), 33 \pm 1 psu, antibiotics (as previously) and low bottom aeration. To exclude the possibility of cannibalism, adults were placed in 50mL Falcon tubes ${ }^{\circledR}$ (whose lid had been cut to allow the stalk through and sealed with Parafilm), with the stalk towards the inside of the tube and the capitulum on the outside. The tubes were filled with FSW and 50 cyprids were added to each replicate tube $\left(1\right.$ larva $\left.\mathrm{ml}^{-1}\right)$. The tubes were then sealed and placed inside conical flasks, to allow the adult to be submerged and extend its cirri. The larvae could swim inside the tube, with the adult stalk and the inner surface of the polypropylene tube as alternative settlement substrata (Fig. 1). Each treatment comprised 9 adults, one per tube assembly, with 50 cyprids from the same batch (except for Exp. 6, in which cyprids were from different batches). Prior to the experiments, all adults were checked for recruits and the stalks were gently cleaned, to ensure comparable experimental conditions and no previous settlement. Except for data collection, the setup was left undisturbed, with no further water changes or feeds.

\section{Exp. 1 Hydrodynamic conditions}

Treatments were selected to facilitate comparison between static conditions (no interference with larval movement) and moving water, either from circular 
currents or turbulence induced by bottom aeration. The static treatment (static) was achieved by leaving the systems (flask and tube) fixed and undisturbed. For moving water (moving), all replicate systems were placed on an orbital shaker (SSL1 Stuart ${ }^{\circledR}$ ) set for constant $30 \mathrm{rpm}$. The aerated treatment (aerated) was achieved by placing weak point aeration inside the adult tube, facilitating larval movement by force of air bubbling inside and allowing the air to escape by means of a secondary tube. A treatment with an air-water interface (interface), identical to the moving treatment, was also established to allow comparison with treatments in which settlement was tested excluding air, as cyprids often become trapped at the air-water interface (Di Fino et al. 2014). This had the tubes containing the adults fully filled with FSW to $0.5 \mathrm{~cm}$ from the top, which allowed a liquid meniscus and air-water interface within each tube. The adults were removed from the conical flasks after $48 \mathrm{~h}$ and the number of larvae permanently attached to the stalk was counted and expressed as a percentage of the initial number of larvae. The adults were then placed back into culture and the water was changed, with unattached cyprids excluded. After 1 week, the adults were observed again for number of metamorphosed larvae, expressed as a percentage of the total number attached at $48 \mathrm{~h}$.

\section{Exp. 2 Temperature}

Each treatment was kept in a separate temperature-controlled incubator (LabHeat $^{\odot}$ and LabCold $^{\odot}$ RLCH0400 Incubator Units), set respectively at 14, 17 or $20^{\circ} \mathrm{C}$. These temperatures are within the range normally experienced by this species in the wild (14$20^{\circ} \mathrm{C}$, Sines, Portugal; Instituto Hidrográfico 2015), during the breeding season that occurs from May to October (Cruz and Araújo 1999). The water temperatures were checked daily (Juwel ${ }^{\circledR}$ Digital Aquarium Thermometer) to ensure that they were maintained within $\pm 1^{\circ} \mathrm{C}$. Settlement (portion attached and portion that subsequently metamorphosed) was recorded and expressed as in Exp. 1.

\section{Exp. 3 Salinity}

Larval culture of this species has commonly been done at 33-37 psu (Coelho 1990, Molares 1994, Molares et al. 1994), with natural salinity on the Portuguese coast varying between 35.8 and 36.0 psu, depending on up/down welling dominance (Bischof et al. 2003) and further sea surface variations due to precipitation, river efflux and evaporation (Talley 2002). However, results of previous laboratory trials showed no differences in attachment and metamorphosis of larvae reared at 32-40 psu (umpub. results). Therefore, three salinity treatments, 20, 30 and $40 \mathrm{psu}$, were used in order to assess tolerance in a wider range. The salinity of each treatment was checked daily (Hand-Held Refractometer $\mathrm{B}+\mathrm{S}^{\odot}$ ) and adjusted as necessary so that variations were $<1$ psu. Settlement was recorded and expressed as in Exp. 1.

\section{Exp. 4 Light}

This experiment comprised two assays. The effect of light and dark conditions, and shade were examined in choice (lighted side versus shaded side of adult stalk) and no-choice assays (illumination versus dark), respectively. All treatments were kept in photoperiod-

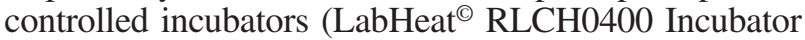
Unit). Where lighting was used, the light intensity was $1233 \pm 145$ lux (Osram Fluora ${ }^{\circledR}$, L 36W/77). A total of 27 adults were used in the experiment: 9 in the dark $(0: 24$ L/D); 9 in full light $(0: 24 \mathrm{~L} / \mathrm{D})$; and the remaining 9 subjected to incident light on one side so that they were shaded on the other. Tubes in the light versus shade assay were fixed inside each conical flask and marked according to which side was in full light and which was in relative shade. The larvae were then able to swim freely and settle on the selected area (light or shade). For the no-choice assays, the numbers of permanently attached and metamorphosed individuals were counted and expressed as in Exp. 1. For the choice assay, attached and metamorphosed individuals on the lighted and shaded sides of each adult stalk were recorded and expressed as a percentage of the number of initial larvae added.

\section{Exp. 5 Cyprid age}

Newly metamorphosed cyprids were filtered from culture, separated into replicate groups and then aged at the culture temperature for 0,3 or 6 days. Replicate groups were kept in $0.2 \mu \mathrm{m}$ natural $\mathrm{FSW}$, at $20 \pm 1^{\circ} \mathrm{C}$, 0:24 L/D, 33 \pm 1 psu until assayed. Settlement was recorded and expressed as in Exp. 1.

\section{Exp. 6 Larval batch}

This experiment examined whether larvae from different batches (termed A, B and C) cultured under identical conditions but collected from distinct groups of adults (collected from the same location) over three consecutive years (in June 2011, 2012 and 2013) had comparable rates of settlement. Egg lamellae were extracted from different wild-collected adults $(n=30)$ and after hatching the nauplii were cultured to the cyprid stage as described previously. Settlement was recorded and expressed as in Exp. 1.

\section{Exp. 7 Rate of settlement}

Percentage permanent attachment on adults $(\mathrm{n}=9)$ was determined at 24, 48, 72 and 96 hours as in Exp. 1. No water changes were made to any of the replicates to avoid associated mortality. Metamorphosis of attached larvae on adults $(n=9)$ was monitored from 48 h postattachment at 3-day intervals, up to and including day 12. For the latter assay, the water was changed at $48 \mathrm{~h}$ to exclude unattached cyprids, so that time to metamorphosis of attached cyprids could be accurately determined.

\section{Exp. 8 Cyprid survival over time}

This experiment examined survival of the cyprids in culture in the absence of settlement substrata (con- 
specific adults), using nine replicate sets of larvae from the same batch. Survival was monitored every $48 \mathrm{~h}$ over a period of 20 days. The seawater from replicate tubes was sieved through a $60-\mu \mathrm{m}$ mesh every $48 \mathrm{~h}$. The number of live cyprids was counted under a stereomicroscope and expressed as a percentage of the total number of cyprids retained on the sieve.

\section{Statistical analyses}

Results were analysed using Statistica ${ }^{\circledR}$, with a significance level of 0.05 . Data analysis was carried out on the basis of homogeneity of variances (Levene's test) and normality (Kolmogorov-Smirnov test), while significant differences were detected by using one-way ANOVA, followed by a post-hoc Tukey HSD test when relevant. Data as percentages were arcsine transformed pre-analysis. When only two treatments were being compared (e.g. light-shade choice assay) a Student t-test was used for dependent or independent samples, as appropriate. Regressions were used to analyse effects over time on permanent attachment, metamorphosis and survival of the larvae. The curves presented were selected by significance $(F$ and $\mathrm{p}$-values) and best fit $\left(\mathrm{R}^{2}\right)$ within the measured range and are not a basis for extrapolation outside of this context. All results are presented as the mean $\pm \mathrm{SD}$, unless stated otherwise.

\section{RESULTS}

\section{Hydrodynamic conditions, temperature, salinity and light}

Permanent attachment and metamorphosis (settlement) of larvae on adults, according to the different environmental conditions of hydrodynamics, temperature, salinity, light and the cyprid-related factors of age and batch, are shown in Figures 2 and 3 (A to F). Permanent attachment varied significantly with hydrodynamic conditions (ANOVA; $\mathrm{F}=14.26, \mathrm{p}<0.01$; Fig. 2A), being lower in the static condition (12.67 \pm $4.87 \%)$ than in the other treatments $(29.93 \pm 9.13 \%$; Tukey's test; $\mathrm{p} \leq 0.01$ ), which were not significantly different from each other (Tukey's test; $\mathrm{p} \geq 0.17$ ). Larvae maintained in static conditions were less active than those kept in hydrodynamic conditions. Larvae in the interface treatment tended to swim close to the water surface and settled on the adult stalk just beneath the meniscus. The percentage of larvae metamorphosing within one week of adding cyprids was not affected by hydrodynamic conditions (ANOVA, F=0.29, $\mathrm{p}=0.83$; Fig. 3A), averaging 73.81 $\pm 10.02 \%$.

Though cyprids kept at higher temperatures were considerably more active than those kept at lower temperatures, no significant differences were observed for permanent attachment (ANOVA, $\mathrm{F}=0.30, \mathrm{p}=0.75$; Fig. 2B), which averaged $32.30 \pm 12.36 \%$ across treatments. However, total metamorphosis over the first week varied significantly according to treatment (ANOVA, $\mathrm{F}=9.01, \mathrm{p}<0.01$; Fig. 3B), increasing in line with temperature from $59.78 \pm 11.43 \%$ at $14^{\circ} \mathrm{C}$ to $79.22 \pm 7.33 \%$ at $20^{\circ} \mathrm{C}$ ( significantly different from each other; Tukey Test, $\mathrm{p}<0.01)$.

Salinity affected both permanent attachment (ANO$\mathrm{VA}, \mathrm{F}=5.68, \mathrm{p}<0.01$ ) and metamorphosis (ANOVA, $\mathrm{F}=13.36, \mathrm{p}<0.01$ ) (Figs $2 \mathrm{C}$ and $3 \mathrm{C}$ ). Permanent attachment was significantly lower at 20 psu $(23.78 \pm 5.93 \%$; Tukey's test, $\mathrm{p} \leq 0.04$ ) than at 30 and 40 psu (on average $31.56 \pm 5.52 \%$ ). The same pattern was observed for metamorphosis: $52.11 \pm 8.51 \%$ at 20 psu and an average of $69.11 \pm 8.37 \%$ at higher salinities (30 and $40 \mathrm{psu}$; Tukey's test, $\mathrm{p}<0.01)$.

Cyprid permanent attachment in the light was approximately double that in the dark (Table 1: light vs. dark-no choice; t-test-independent samples, $\mathrm{df}=16$, $\mathrm{p}<0.01)$. This preference for attachment in light conditions was confirmed in the choice assay (Table 1: light or shade choice; t-test-dependent samples, $\mathrm{df}=8$, $\mathrm{p}<0.01$ ), where of the $33.11 \pm 6.51 \%$ of cyprids that attached, $26.11 \pm 6.13 \%$ did so on the illuminated side and $7.00 \pm 1.93 \%$ on the shaded side. No differences were observed in metamorphosis within the first week between different light conditions (Table 1; no-choice, t-test-independent samples, $\mathrm{df}=16, \mathrm{p}=0.67$; choice, t-test-dependent samples, $\mathrm{df}=8, \mathrm{p}=0.48)$, which averaged $72.82 \pm 6.92 \%$.

\section{Cyprid age and batch}

The age of cyprids (Figs 2E and 3E) significantly affected permanent attachment (ANOVA, $F=8.60$, $\mathrm{p}<0.01$ ) and metamorphosis (ANOVA, $\mathrm{F}=5.47$, $\mathrm{p}=0.01)$. Larvae in all groups appeared healthy, with visible numbers of lipid droplets. Permanent attachment was higher for aged larvae $(32.89 \pm 5.09 \%$ for 3-day-old and 36.89 $\pm 3.59 \%$ for 6-day-old larvae; not significantly different; Tukey's test; $\mathrm{p}=0.30$ ) than un-aged larvae $(26.44 \pm 6.84 \%$; Tukey's test, $\mathrm{p} \leq 0.04)$. Successful metamorphosis within the first week decreased with ageing and was significantly lower for cyprids aged for 6 days than for those aged for 3 days (60.89 $\pm 7.83 \%$; Tukey's test, $\mathrm{p}=0.01)$.

Permanent attachment (ANOVA, $\mathrm{F}=4.12$, $\mathrm{p}=0.03$ ) and metamorphosis rate (ANOVA, $\mathrm{F}=7.36$,

Table 1. - Permanent attachment $\left(\% 48 \mathrm{~h}^{-1}\right)$ and metamorphosis (\% $\mathrm{w}^{-1}$ ) of larvae allowed to settle on adults, in culture, under different lighting conditions. Treatments were as follows: (dark-no choice) 0:24 L/D photoperiod in a no-choice assay; (light-no choice) 24/0 L/D photoperiod, created by multiple surrounding light sources in a no-choice assay; (light or shade-choice) 24:0 L/D photoperiod, created by a single light source in a double-choice assay between the side directly exposed to light (light) and shaded from light (shade). Cyprid numbers for the choice assay were counted for both light and shade sides separately and added to calculate the total values for the light or shade choice values. Differences between treatments were significant for permanent attachment (ANOVA, $\mathrm{F}=39.89, \mathrm{p}<0.01$ ) but not metamorphosis (ANOVA, $\mathrm{F}=0.34, \mathrm{p}=0.84$ ). Values are presented as mean \pm SD.

\begin{tabular}{lcc}
\hline \multicolumn{1}{c}{ Light } & $\begin{array}{c}\text { Permanent attachment } \\
(\%)\end{array}$ & $\begin{array}{c}\text { Metamorphosis } \\
(\%)\end{array}$ \\
\hline Dark-no choice & $18.00 \pm 5.48$ & $73.89 \pm 9.17$ \\
Light-no choice & $35.44 \pm 6.29$ & $71.56 \pm 6.04$ \\
Light or shade-choice & $33.11 \pm 6.51$ & $72.89 \pm 3.54$ \\
Light exposed & $26.11 \pm 6.13$ & $71.33 \pm 6.10$ \\
Shaded & $7.00 \pm 1.94$ & $74.44 \pm 9.19$ \\
\hline
\end{tabular}



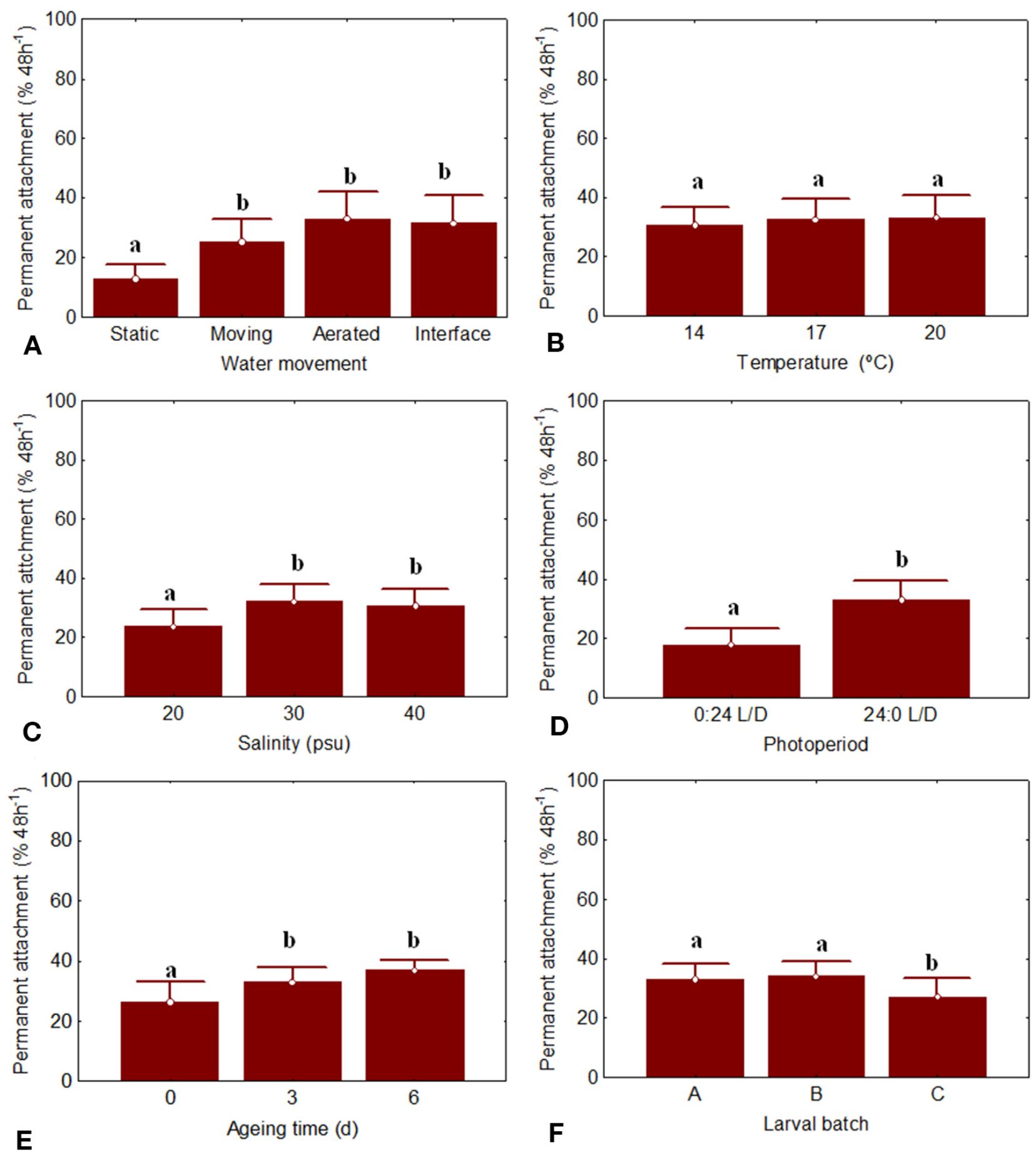

Fig. 2. - Permanent attachment ( $\% 48 \mathrm{~h}^{-1}$; mean \pm SE) of $P$. pollicipes larva, allowed to settle on the adults in culture under various environmental conditions of hydrodynamics (A), temperature (B), salinity (C) and light (D), as well the cyprid-related factors of cyprid age (E) and batch origin (F). Hydrodynamic conditions tested (A) were as follows: (static) no water movement, (moving) circular water movement, (aerated) water kept under constant aeration and (interface) surface not fully submersed, but with interface between air and water. Temperatures tested (B) included 14,17 and $20^{\circ} \mathrm{C}$, and salinities (C) were 20,30 and 40 psu. Light treatments (D) were as follows: (0:24 L/D) full dark photoperiod and (24/0 L/D) full light photoperiod. Cyprid ageing $(\mathrm{E})$ was done for 0,3 and 6 days and batches tested $(\mathrm{F})$ were collected from adults during the breeding seasons of 2011 (A), 2012 (B), and 2013 (C).

$\mathrm{p}<0.01)$ varied with larval batch (Figs $2 \mathrm{~F}$ and $3 \mathrm{~F})$. These differences were significant between batches $\mathrm{A}$ or $\mathrm{B}$ and $\mathrm{C}$ for permanent attachment (Tukey's test, $\mathrm{p}=0.04$ ) as well as between $\mathrm{B}$ and $\mathrm{A}$ or $\mathrm{C}$ for metamorphosis (Tukey's test, $\mathrm{p} \leq 0.01$ ); all other comparisons were not significantly different
(Tukey's test; $\mathrm{p} \geq 0.08$ ). Permanent attachment varied between $27.00 \pm 6.48$ and $34.11 \pm 5.06 \%$, while metamorphosis ranged between $55.22 \pm 7.83$ and $69.33 \pm 9.28 \%$. It is important to note that the measure of metamorphosed larvae is always expressed as a percentage of the total larvae attached at $48 \mathrm{~h}$ 

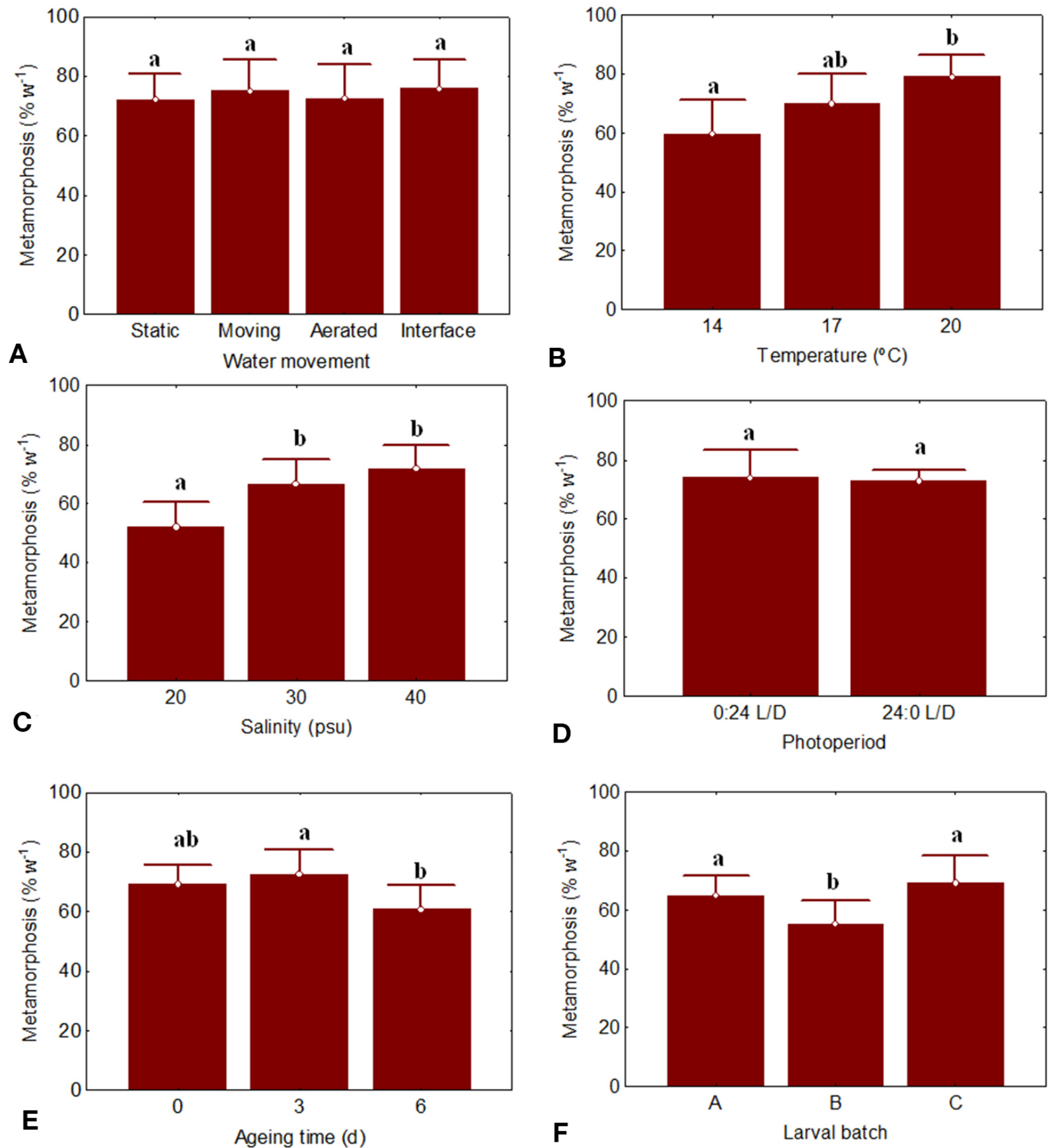

Fig. 3. - Metamorphosis $\left(\% \mathrm{w}^{-1}\right.$; mean \pm SE) of $P$. pollicipes larva allowed to settle on the adults in culture under various environmental conditions of hydrodynamics (A), temperature (B), salinity (C) and light (D), as well the cyprid-related factors of cyprid age (E) and batch origin (F). Hydrodynamic conditions tested (a) were as follows: (static) no water movement, (moving) circular water movement, (aerated) water kept under constant aeration and (interface) surface not fully submerged, but with interface between air and water. Temperature tested (B) included 14,17 and $20^{\circ} \mathrm{C}$, and salinities (C) were 20, 30 and 40 psu. Light treatments (D) were as follows: (0) 0:24 L/D photoperiod on a no-choice assay; (1) 24/0 L/D photoperiod, created by all surrounding light, in a no-choice assay; (2) 24:0 L/D photoperiod, created with a single light source, on a double-choice assay between the side directly exposed to light (light) and the side shaded from light (shade). Cyprid ageing $(\mathrm{E})$ was done for 0,3 and 6 days and batches tested $(\mathrm{F})$ were collected from adults during the breeding seasons of 2011 (A), 2012 (B) and 2013 (C).

and not as the percentage of larvae added initially. Batch differences accounted for variations of the order of $7 \%$ and $15 \%$ for permanent attachment and metamorphosis, respectively, for groups of larvae reared under similar conditions but collected in consecutive years.

\section{Rate of settlement and cyprid survival over time}

Significant differences were recorded for permanent attachment with time (Fig. 4A; polynomial regression: $y=-0.0043 \mathrm{x}^{2}+0.74 \mathrm{x}-0.33, \mathrm{x} \in[0,96] ; \mathrm{R}^{2}=0.99$, $\mathrm{F}=133.67, \mathrm{p}<0.01)$. Attachment increased over the first 

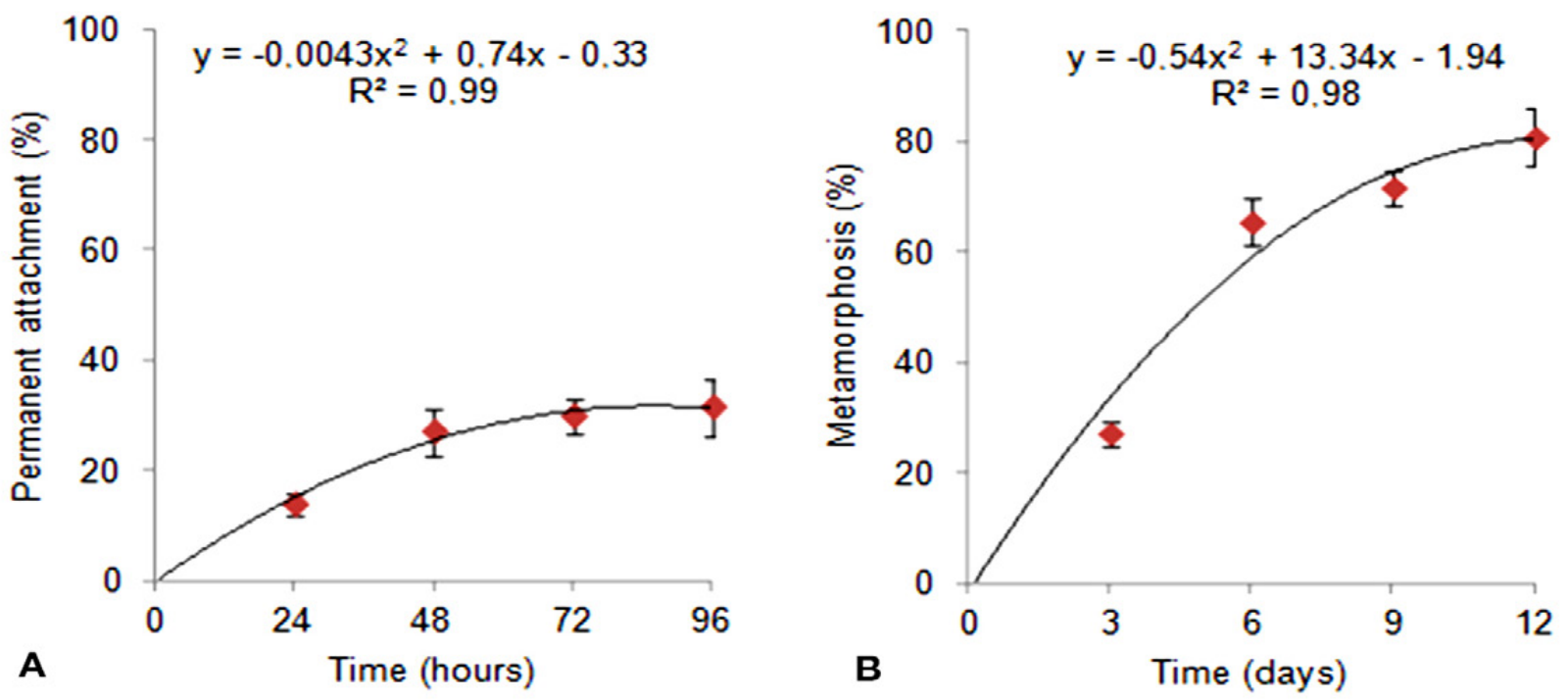

Fig. 4. - Permanent attachment (A -\%; mean \pm SD) and metamorphosis (B - \%; mean \pm SD) of larvae allowed to settle on adults in culture, with time. Permanent attachment was observed at 24-h intervals for a period of $96 \mathrm{~h}$, while metamorphosis was monitored every 3 days for a period of 12 days post-attachment. The fitted curves for permanent attachment (polynomial regression: $y=-0.0043 x^{2}+0.74 x-0.33, x \in[0,96] ; R^{2}=0.99$, $\mathrm{F}=133.67, \mathrm{p}<0.01$ ) and metamorphosis (polynomial regression: $\mathrm{y}=-0.54 \mathrm{x}^{2}+13.34 \mathrm{x}-1.94, \mathrm{x} \in[0,12] ; \mathrm{R}^{2}=0.98, \mathrm{~F}=48.76, \mathrm{p}=0.02$ ) for the present data are also shown.

$48 \mathrm{~h}$, after which it stabilized at around 30\%. Similarly, the rate of metamorphosis also changed with time (Fig. $4 \mathrm{~B}$; polynomial regression: $\mathrm{y}=-0.54 \mathrm{x}^{2}+13.34 \mathrm{x}-1.94$, $\mathrm{x} \epsilon[0,12] ; \mathrm{R}^{2}=0.98, \mathrm{~F}=48.76, \mathrm{p}=0.02$ ), increasing to $80.67 \pm 4.97 \%$ by day 12 . About $10 \%$ of cyprids failed to metamorphose even after 18 days.

When larval survival in culture was evaluated in the absence of settlement substrata, cyprids lived for extended periods, with mortality after 20 days at around $50 \%$. Survival decreased significantly with time (Fig. 5; polynomial regression: $\mathrm{y}=-0.09 \mathrm{x}^{2}+0.69 \mathrm{x}+100.34$, $\left.\mathrm{x} \epsilon[0,20] ; \mathrm{R}^{2}=0.99, \mathrm{~F}=1479.23, \mathrm{p}<0.01\right)$. Survival for the first 6 days post-metamorphosis to the cyprid was over $95 \%$, thereafter declining gradually until day 16 (to $\approx 70 \%$ ), at which point a steeper decline commenced (Fig. 5). Cyprid activity also declined with time, as did visible lipid reserves (oil droplets). Living cyprids were observed even after 30 days in culture, although the amount of available lipid was virtually non-existent and cyprid activity was minimal.

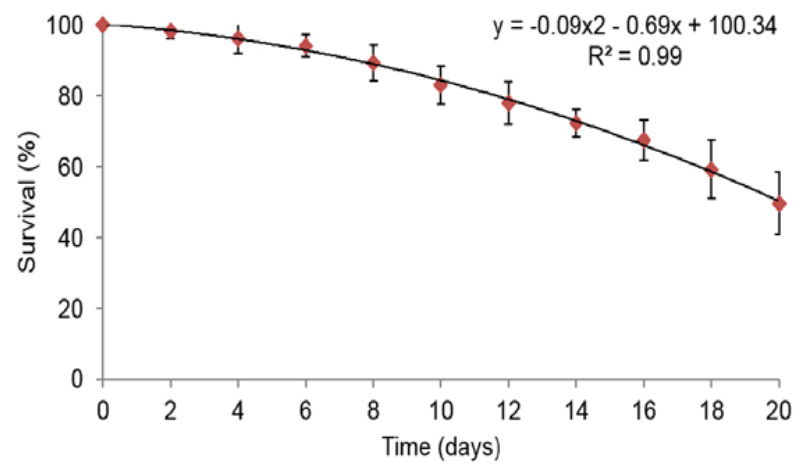

Fig. 5. - Cyprid survival (\%; mean \pm SD) according to time in culture. Monitoring was done at two-day intervals for a period of 20 days. The fitted curve (polynomial regression: $y=-0.09 x^{2}+0.69 x+100.34$, $\left.\mathrm{x} \in[0,20] ; \mathrm{R}^{2}=0.99, \mathrm{~F}=1479.23, \mathrm{p}<0.01\right)$ for the present data is also shown.

\section{DISCUSSION}

\section{Effects of environmental conditions on settlement}

Environmental conditions (hydrodynamics, light, salinity and temperature) and their effects on settlement were investigated. The effects of water movement on barnacle settlement have been widely studied (e.g. Crisp 1955, Mullineaux and Butman 1991). In the present study, permanent attachment was lower in static conditions, suggesting that dynamic conditions favour settlement. This is in agreement with the conditions experienced by larvae in the natural environment, where flow is highly turbulent. Though the method of water agitation used in this study either facilitated (e.g. aeration) or hindered (e.g. orbital shaker) the circulation of cyprids, no significant differences in attachment or metamorphosis were found according to the type of hydrodynamism, supporting the notion that transport of cyprids to a suitable surface is more important than the flow characteristics. The lack of a difference in the rate of metamorphosis according to hydrodynamic conditions further implied that there was no significant difference in energy expenditure in each treatment. Interestingly, in the air-water interface condition, cyprids were observed at the water meniscus and out of water stuck to the surface. When observed under the stereomicroscope, $P$. pollicipes cyprids that had settled out of the water appeared to be covered by a thin layer of water, protecting them from desiccation. The same was observed for the cyprids attached to adult stalks, which were mostly found settled in between the scales. It is unclear whether this attachment pattern at the meniscus is an adaptive characteristic, which in nature may serve to target upper water column levels, or an artefact of laboratory rearing (see Di Fino et al. 2014).

The effects of salinity on settlement have been investigated for several barnacle species (e.g. B. im- 
provisus, B. eburneus, B. subalbidus; Dineen and Hines 1992, 1994a,b). For P. pollicipes, cyprid exploration and attachment decreased $(\approx 10 \%$ at $20 \mathrm{psu})$ at salinities below natural (30-40 psu), in a similar way to metamorphosis rate $(\approx 20 \%)$. $P$. pollicipes inhabit coastal environments where salinity ranges between 33 and $37 \mathrm{psu}$ and it is therefore not surprising that larvae are better adapted to survive and develop within this range. Regulatory mechanisms needed to cope with sub-natural salinities, or the recognition of sub-optimal conditions, might lead to a decrease in surface exploration, but also a reduced capacity to metamorphose. Nevertheless, the tolerance to lower salinities (e.g. 20 $\mathrm{psu}$ ) is indicative of physiological plasticity, as seen in other barnacle species (e.g. B. amphitrite, Kon-Ya and Miki 1994). This increased tolerance to a range of salinities might relate to their adaptation to the highlyexposed intertidal, where larvae can be subjected to situations of higher salinity (e.g. after water evaporation on rock pools during low tide) or lower salinity on the surface water layer (e.g. after precipitation). Other authors (e.g. Dineen and Hines 1994a, b) have observed that the response to salinity varies significantly with species selectivity, correlating with their distribution range, but can also be heavily influenced by other factors such as age and the use of barnacle extracts, which contain settlement pheromone (Clare 2011).

The mostly positive phototactic behaviour of $P$. pollicipes nauplii (Molares et al. 2002) also has ecological advantages by placing larvae higher in the water column, thus facilitating their feeding on phytoplankton. In nature, larvae are also subjected to long-day photoperiods during the breeding season. In this study, the overall preference was for permanent attachment in illuminated areas, with rates almost four times higher than those in the shaded areas. Results from other studies indicate that settlement can vary with light, with many species showing positive phototaxis and with species-specific preferences for settlement under direct or diffuse light (e.g. Daniel 1957, Crisp and Ritz 1973, Pawlik 1992), which have been suggested to be adaptive responses. The lack of difference in metamorphosis rate suggests that this process is independent of light.

Temperature has well-documented effects on barnacle larval development and survival (Satuito et al. 1996, Marechal et al. 2004). Results from Coelho (1990) indicate that the use of higher temperatures significantly decreases larval development time in $P$. pollicipes, as well as survival. This also applies to barnacle cyprids, as higher temperatures increase metabolic rate and oxygen consumption, with effects on the depletion of energy reserves and a reduction in competence to settle (Satuito et al. 1996). Studies on other species (e.g. Thiyagarajan et al. 2003) have shown that settlement can vary according to temperature. Although permanent attachment was not influenced by temperature, metamorphosis rate was higher $(\geq 20 \%)$ at higher temperatures $\left(17\right.$ and $20^{\circ} \mathrm{C}$ ). This can be related to temperature accelerating development in the first week and not necessarily implying a higher rate of metamorphosis at these temperatures. For example, B. amphitrite larvae reared at $20^{\circ} \mathrm{C}$ could successfully metamorphose over a shorter period than those reared at $30^{\circ} \mathrm{C}$ (Anil et al. 2001). Moreover, Pechenik et al. (1993) reported that cyprids that were forced to delay metamorphosis showed slow post-settlement growth, in spite of the lack of effects on completion of metamorphosis and post-settlement survival, highlighting the need for further investigation in $P$. pollicipes. In nature, temperatures over the breeding season vary between 14 and $20^{\circ} \mathrm{C}$ from May to October, tending to the upper range from July to September. Faster metamorphosis at higher temperatures might therefore confer a competitive advantage during this period.

\section{Larval condition, origin and settlement over time}

Of the cyprid-related factors that might affect settlement on conspecifics in culture, only ageing and larval batch were investigated. Cyprids of Balanus amphitrite become less selective for substrata as they age (Rittschof et al. 1984), consistent with the 'desperate larva hypothesis' (Toonen and Pawlik 1994). In the present experiments with $P$. pollicipes, attachment also increased as larvae aged. Rittschof et al. (1984) also reported that age-dependent responses of cyprids decrease in the presence of settlement inducers, which suggests that if settlement was being tested on substrata other than the adult, these settlement differences could be higher. The temperature at which cyprids are aged is also crucial to this effect. Satuito et al. (1996) found that storage protein (cyprid major protein) in $B$. amphitrite decreases with time when ageing is carried out at 15,20 and $25^{\circ} \mathrm{C}$, but not at $5^{\circ} \mathrm{C}$. However, longer ageing implies decreased storage reserves, which signify reduced competence, or ability to metamorphose, in aged cyprids (Holland and Walker 1975, Lucas et al. 1979, Satuito et al. 1996). This seems to be the case for $P$. pollicipes in which, after a week, fewer metamorphosed cyprids were observed in stocks aged for 6 days. However, this does not necessarily imply an absolute decrease in metamorphosis, but rather a possible decrease in rate. A settled cyprid will always attempt to moult to a juvenile barnacle (West and Costlow 2005) although a minimum oil cell volume is required to ensure successful metamorphosis. As cyprids age, therefore, the number of cyprids incapable of completing metamorphosis will increase. Furthermore, it should be noted that post-settlement growth can decrease in aged barnacle cyprids, even if metamorphosis rate is not affected (Pechenik et al. 1993). There are also interesting implications with regard to what might be happening in the wild. Barnacle cyprids are known to postpone their settlement for varying periods that differ between species (Knight-Jones 1953, Krug 2006). However, although cyprids of $P$. pollicipes might be able to survive in the wild for long periods, the ability to successfully attach and metamorphose will likely decrease steadily with time, selecting only the fittest individuals. In the laboratory, S. balanoides lasted 28 days $\left(10^{\circ} \mathrm{C}\right)$ on energy reserves, after which the capacity to metamorphose was compromised due to a drop in reserves below the critical minimum for moulting (Lucas et al. 1979). As the quantity of the storage reserves will 
determine how long settlement can be delayed until a settlement site is identified, the timing of larval release and development rate is of paramount importance.

Batch differences also affected permanent attachment and metamorphosis and could impact the variability of recruitment in the wild. Although in the present study the maximum attachment differences were about $10 \%$, Holm et al. (2000) reported differences of $10 \%$ to $40 \%$ in settlement for different batches of $B$. amphitrite larvae, most likely due to parental as well as environmental effects.

The present study presents the first reference values for $P$. pollicipes larval permanent attachment over time, which follow patterns previously reported for other species (e.g. Rittschof et al. 1984). Metamorphosis was no exception, with approximately $80 \%$ of larvae moulting within 12 days and about $10 \%$ of larvae failing to metamorphose. Kugele and Yule (1996) reported a similar pattern, with $64 \%$ of cyprids metamorphosing in 6 days, $18 \%$ failing to metamorphose, and negligible settlement on non-conspecific substrata. The percentage of cyprids failing to metamorphose in the laboratory suggests that the health of laboratoryreared larvae is certainly an issue to consider.

Cyprid survival in the absence of conspecific substrata showed a steady rate of decline to $\approx 50 \%$ after 20 days in culture, reflecting the larval capacity to survive over long periods in the water column. It is further hypothesized that, during summer, the long survival could be prolonged by periods of colder water temperatures associated with upwelling events (Fiuza et al. 1982). Increasing lethargy of larvae over this period might represent an energy-saving strategy to survive for long periods in the wild, when settlement is not possible and larvae are dependent on currents for suitable on-shore transport. However, results for other species indicate particularly long cyprid phases for larvae reared in culture (Batham 1946) and it cannot be excluded that these may be overestimations of survival in the wild.

The results of this study constitute the first laboratory investigation into some of the factors modulating gregarious settlement of this species. Gregariousness occurred over a range of conditions, but attachment and metamorphosis were influenced independently by the various experimental treatments. Larval-related factors affected both attachment and metamorphosis, with cyprid age decreasing both rates. Larvae were nevertheless capable of surviving for extended periods. All abiotic factors tested (except temperature) affected permanent attachment, which was optimal under conditions of light, salinity and hydrodynamics similar to those experienced in nature. On the other hand, metamorphosis was affected by neither light nor hydrodynamism, but was higher at natural salinities and higher temperatures, conditions consistent with the breeding season (Cruz and Araújo 1999) and downwelling periods (Fiuza et al. 1982). Although these observations might suggest that $P$. pollicipes cyprids could cope well with predicted temperature and salinity fluctuations in the North Atlantic Ocean, further studies should investigate the interaction of these factors, particularly within the context of climate change. Furthermore, although larvae settled heavily on conspecific adults, habitat selection in nature is likely to be mediated by a variety of factors beyond those addressed here, such as transport to the coast, larval choice and post-settlement survival. Further research on the importance of substrata-related factors, both abiotic (e.g. surface topography, desiccation) and biotic (e.g. presence of incumbents, including biofilm, predation, competition and chemical signals/ cues), is essential to understand how the interaction of these factors modulates recruitment and constitutes an essential tool for stock management programmes.

\section{ACKNOWLEDGEMENTS}

This work was supported by the Fundação para a Ciência e Tecnologia, research grant SFRH/ BD/63998/2009 to S.C. Franco, financed by the Programa Operacional Potencial Humano (POPH-QREN) and co-financed by the European Social Fund (ESF, European Union). The authors would like to thank Pietro Di Modica for the CAD model and drawing. The authors would further like to thank the colleagues at Laboratório de Ciências do Mar (CIEMAR) for their assistance with fieldwork and invaluable technical support. SCF and NA acknowledge funding from the Office of Naval Research Grants N00014-08-1-1240 and N00014-13-1-0634 to ASC and N00014-13-1-0633 to ASC and NA.

\section{REFERENCES}

Aldred N., Clare A.S. 2009. Mechanisms and principles underlying temporary adhesion, surface exploration and settlement site selection by barnacle cyprids: A short review. In: Gorb S.N. (ed.) Functional surfaces in biology. Springer. Netherlands, pp. 43-65. http://dx.doi.org/10.1007/978-1-4020-6695-5 3

Aldred N., Gohad N.V., Petrone L., et al. 2013. Confocal microscopy-based goniometry of barnacle cyprid permanent adhesive. J. Exp. Biol. 216: 1969-1972.

http://dx.doi.org/10.1242/jeb.084913

Anil A.C., Desai D., Khandeparker L., 2001. Larval development and metamorphosis in Balanus amphitrite Darwin (Cirripedia, Thoracica): significance of food concentration, temperature and nucleic acids. J. Exp. Mar. Biol. Ecol. 263: 125-141. http://dx.doi.org/10.1016/S0022-0981(01)00280-5

Barnes M.G. 1996. Pedunculate cirripedes of the genus Pollicipes. Oceanogr. Mar. Biol. 34: 303-394.

Batham E. 1946. Pollicipes spinosus Quoy and Gamard, II: embryonic and larval development. Trans. Roy. Soc. New Zeal. 75: 405-418.

Bertness M.D., Gaines S.D., Wahle R.A. 1996. Wind-driven settlement patterns in the acorn barnacle Semibalanus balanoides. Mar. Ecol. Progr. Ser. 137: 103-110. http://dx.doi.org/10.3354/meps 137103

Bischof B., Mariano A.J., Ryan E.H. 2003. The Portugal current system. Surface Currents in the Atlantic Ocean. http://oceancurrents.rsmas.miami.edu/atlantic/portugal.html.

Borja A., Muxika I., Bald J. 2006. Protection of the goose barnacle Pollicipes pollicipes, Gmelin, 1790 population: the Gaztelugatxe Marine Reserve (Basque Country, northern Spain). Sci. Mar. 70: 235-242 http://dx.doi.org/10.3989/scimar.2006.70n2235

Clare A.S. 2011. Towards the characterization of the chemical cue to barnacle gregariousness. Chemical communications in crustaceans. Springer, New York, pp. 431-455.

Clare A.S., Thomas R.F., Rittschof D. 1995. Evidence of the involvement of cyclic AMP in the pheromonal modulation of barnacle settlement. J. Exp. Mar. Biol. 198: 655-664.

Coelho M.R. 1990. Descrição dos estados larvares do perceve (Pollicipes cornucopia). Faro, Portugal: Universidade do Algarve, pp. 39. 
Coelho M.R. 1991. A field study on Pollicipes pollicipes settlement. Wales, UK: University of Wales, pp. 29.

Crisp D.J. 1955. The behaviour of barnacle cyprids in relation to water movement over a surface. J. Exp. Mar. Biol. 32: 569-590.

Crisp D.J., Barnes H. 1954. The orientation and distribution of barnacles at settlement with particular reference to surface contour. J. Anim. Ecol. 23: 142-162. http://dx.doi.org/10.2307/1664

Crisp D.J., Ritz D.A. 1973. Responses of cirripede larvae to light. I. Experiments with white light. Mar. Biol. 23: 327-335. http://dx.doi.org/10.1007/BF00389340

Cruz T., Araújo J. 1999. Reproductive patterns of Pollicipes pollicipes (Cirripedia: Scalpellomorpha) on the Southwestern coast of Portugal. J. Crust. Biol. 19: 260-267. http://dx.doi.org/10.2307/1549232

Cruz T., Castro J.J., Hawkins S.J. 2010. Recruitment, growth and population size structure of Pollicipes pollicipes in SW Portugal. J. Exp. Biol. 392: 200-209. http://dx.doi.org/10.1016/j.jembe.2010.04.020

Daniel A. 1957. Illumination and its effect on the settlement of barnacle cyprids. Proc. Zool. Soc. Lon. 129: 305-313. http://dx.doi.org/10.1111/j.1096-3642.1957.tb00295.x

Di Fino A., Petrone L., Aldred N., et al. 2014. Correlation between surface chemistry and settlement behaviour in barnacle cyprids (Balanus improvisus). Biofouling 30: 143-152. http://dx.doi.org/10.1080/08927014.2013.85254

Dineen J.F., Hines A.H. 1992. Interactive effects of salinity and adult extract upon settlement of the estuarine barnacle $\mathrm{Bal}$ anus improvisus (Darwin, 1854). J. Exp. Mar. Biol. Ecol. 156: 239-252. http://dx.doi.org/10.1016/0022-0981(92)90249-A

Dineen J.F., Hines A.H. 1994a. Larval settlement of the polyhaline barnacle Balanus eburneus (Gould): cue interactions and comparisons with two estuarine congeners. J. Exp. Mar. Biol. Ecol. 179: 223-234. http://dx.doi.org/10.1016/0022-0981(94)90116-3

Dineen J.F., Hines A.H. 1994b. Effects of salinity and adult extract on settlement of the oligohaline barnacle Balanus subalbidus. Mar. Biol. 119: 423-430. http://dx.doi.org/10.1007/BF00347539

Dreanno C., Kirby R.R., Clare A.S. 2006. Smelly feet are not always a bad thing: The relationship between cyprid footprint protein and the barnacle settlement pheromone. Biol. Lett. 2: 423-425. http://dx.doi.org/10.1098/rsbl.2006.0503

Fiuza A.F., Macedo M.E., Guerreiro M.R. 1982. Climatological space and time variation of the Portuguese coastal upwelling. Oceanologica Acta. 5: 31-40.

Holland D.L., Walker G. 1975. The biochemical composition of the cypris larva of the barnacle Balanus balanoides L. J. Conseil 36: $162-165$. http://dx.doi.org/10.1093/icesjms/36.2.162

Holm E.R. 2012. Barnacles and biofouling. Int. Comp. Biol. 52: 348-355. http://dx.doi.org/10.1093/icb/ics042

Holm E.R., McClary M., Rittschof D. 2000. Variation in attachment of the barnacle Balanus amphitrite: sensation or something else? Mar. Ecol. Progr. Ser. 202: 153-162. http://dx.doi.org/10.3354/meps202153

Instituto Hidrográfico. 2015. Instituto Hidrográfico (accessed on 01/12/2015).

http://www.hidrografico.pt

Keough M.J., Raimondi P.T. 1996. Responses of settling invertebrate larvae to bio-organic films: effects of large-scale variation in films. J. Exp. Mar. Biol. Ecol. 207: 59-78. http://dx.doi.org/10.1016/S0022-0981(96)02632-9

Knight-Jones E.W. 1953. Laboratory experiments on gregariousness during setting in Balanus balanoides and other barnacles. J. Exp. Biol. 30: 584-598

Kon-Ya K., Miki W. 1994. Effects of environmental-factors on larval settlement of the barnacle Balanus amphitrite reared in the laboratory. Fish. Sci. 60: 563-565.

Krug P.J. 2006. Defense of benthic invertebrates against surface colonization by larvae: a chemical arms race. Prog. Mol. Subcell Biol. 42: 1-53. http://dx.doi.org/10.1007/3-540-30016-3_1

Kugele M., Yule A.B. 1996. The larval morphology of Pollicipes pollicipes (Gmelin 1970) (Cirripedia: Lepadomorpha) with notes on cyprid settlement. Sci. Mar. 60: 469-480.

Le Tourneux F., Bourget E. 1988. Importance of physical and biological settlement cues used at different spatial scales by the larvae of Semibalanus balanoides. Mar. Biol. 97: 57-66. http://dx.doi.org/10.1007/BF00391245

Lucas M.I., Walker G., Holland D.L., et al. 1979. An energy budget for the free-swimming and metamorphosing larvae of Balanus balanoides (Crustacea: Cirripedia). Mar. Biol. 55: 221-229. http://dx.doi.org/10.1007/bf00396822

Maki J.S., Rittschof D., Costlow J.D., et al. 1988. Inhibition of attachment of larval barnacles, Balanus amphitrite, by bacterial surface films. Mar. Biol. 97: 199-206. http://dx.doi.org/10.1007/BF00391303

Marechal J.P., Hellio C., Sebire M., et al. 2004. Settlement behaviour of marine invertebrate larvae measured by EthoVision 3.0. Biofouling 20: 211-217. http://dx.doi.org/10.1080/08927010400011674

Marechal J.P., Matsumura K., Conlan S., et al. 2012. Competence and discrimination during cyprid settlement in Amphibalanus amphitrite. Int. Biodeter. Biodegrad. 72: 59-66. http://dx.doi.org/10.1016/j.ibiod.2012.05.007

Matsumura K., Nagano M., Kato-Yoshinaga Y., et al. 1998. Immunological studies on the settlement-inducing protein complex (SIPC) of the barnacle Balanus amphitrite and its possible involvement in larva-larva interactions. Proc. Roy. Soc. B 265: 1825-1830. http://dx.doi.org/10.1098/rspb.1998.0508

Matsumura K., Hills J.M., Thomason P.O., et al. 2000. Discrimination at settlement in barnacles: Laboratory and field experiments on settlement behaviour in response to settlement-inducing protein complexes. Biofouling 16: 181-190. http://dx.doi.org/10.1080/08927010009378443

Minchinton T.E., Scheibling R.E. 1993. Free space availability and larval substratum selection as determinants of barnacle population structure in a developing rocky intertidal community. Mar Ecol. Prog. Ser. 95: 233-244. http://dx.doi.org/10.3354/meps095233

Molares J. 1994. Estudio del ciclo biologico del percebe (Pollicipes cornucopia Leach) de las costas de Galicia. Xunta de Galicia, Santiago, Spain, 62 pp.

Molares J., Freire J. 2003. Development and perspectives for community-based management of the goose barnacle (Pollicipes pollicipes) fisheries in Galicia (NW Spain). Fish. Res. 65: 485-492. http://dx.doi.org/10.1016/j.fishres.2003.09.034

Molares J., Tilves F., Pascual C. 1994. Larval development of the pedunculate barnacle Pollicipes cornucopia (Cirripedia: Scalpellomorpha) reared in the laboratory. Mar. Biol. 120: 261-264. http://dx.doi.org/10.1007/BF00349686

Molares J., Otero E.V., Rivero G.M. 2002. Ecologia larvaria del percebe Pollicipes pollicipes: patrones estacionales, mecanismos de control y comportamiento, desde la eclosion hasta la fijación. Informe Final del Proyecto de Investigación. Conselleria de Pesca e Asuntos Maritimos (Centro de Investigacions Marinas), Pontevedra, Spain, $41 \mathrm{pp}$.

Mullineaux L.S., Butman C.A. 1991. Initial contact, exploration and attachment of barnacle (Balanus amphitrite) cyprids settling in flow. Mar. Biol. 110: 93-103. http://dx.doi.org/10.1007/BF01313096

Nott J.A., Foster B.A. 1969. On the structure of the antennular attachment organ of the cypris larva of Balanus balanoides (L.). Philos. T. Roy. Soc. B 256: 115-134. http://dx.doi.org/10.1098/rstb.1969.0038

Pavón C. 2003. Biologia y variables poblacionales del percebe, Pollicipes pollicipes (Gmelin, 1790) en Asturias. Oviedo, Spain: Universidad de Oviedo, $151 \mathrm{pp}$.

Pawlik J.R. 1992. Chemical ecology of the settlement of benthic marine invertebrates. Oceanogr Mar. Biol. Ann. Rev. 30: 273-335.

Pechenik J.A., Rittschof D., Schmidt A.R. 1993. Influence of delayed metamorphosis on survival and growth of juvenile barnacles Balanus amphitrite. Mar. Biol. 115: 287-294. http://dx.doi.org/10.1007/BF00346346

Rittschof D., Branscomb E.S., Costlow J.D. 1984. Settlement and behavior in relation to flow and surface in larval barnacles, $\mathrm{Ba}$ lanus amphitrite Darwin. J. Exp. Mar. Biol. Ecol. 82: 131-146. http://dx.doi.org/10.1016/0022-0981(84)90099-6

Satuito C.G., Shimizu K., Natoyama K., et al. 1996. Age-related settlement success by cyprids of the barnacle Balanus amphitrite, with special reference to consumption of cyprid storage protein. Mar. Biol. 127: 125-130. http://dx.doi.org/10.1007/BF00993652

Shanks A.L. 1986. Tidal periodicity in the daily settlement of intertidal barnacle larvae and hypothesized mechanism for the cross- 
shelf transport of cyprids. Biol. Bull. 170: 429-440. http://dx.doi.org/10.2307/1541852

Sousa A., Jacinto D., Penteado N., et al. 2013. Patterns of distribution and abundance of the stalked barnacle (Pollicipes pollicipes) in the central and southwest coast of continental Portugal. J. Sea Res. 83: 187-194. http://dx.doi.org/10.1016/j.seares.2013.04.005

Talley L.D. 2002. Salinity patterns in the ocean. In: MacCracken M.C., Perry J.S. (eds) The Earth system: physical and chemical dimensions of global environmental change. John Wiley and Sons Ltd., Chichester, pp. 629-640.

Thiyagarajan V., Harder T., Qian P. 2002. Effect of the physiological condition of cyprids and laboratory-mimicked seasonal conditions on the metamorphic successes of Balanus amphitrite Darwin (Cirripedia; Thoracica). J. Exp. Mar. Biol. Ecol. 272: 65-74

http://dx.doi.org/10.1016/S0022-0981(02)00182-X

Thiyagarajan V., Harder T., Qian P. 2003. Combined effects of temperature and salinity on larval development and attachment of the subtidal barnacle Balanus trigonus Darwin. J. Exp. Mar. Biol. Ecol. 287: 223-236.

http://dx.doi.org/10.1016/S0022-0981(02)00570-1

Toonen R.J., Pawlik J.R. 1994. Foundations of gregariousness. Nature 370: $511-512$.

http://dx.doi.org/10.1038/370511a0

Walker G. 1971. A study of the cement apparatus of the cypris larva of the barnacle Balanus balanoides. Mar. Biol. 9: 205-212. http://dx.doi.org/10.1007/BF00351380

West T.L., Costlow J.D. 2005. Determinants of the larval molting pattern of the crustacean Balanus eburneus Gould (Cirripedia: Thoracica). J. Exp. Zool. 248: 33-44. http://dx.doi.org/10.1002/jez.1402480106

Wieczorek S.K. Todd C.D. 1998. Inhibition and facilitation of settlement of epifaunal marine invertebrate larvae by microbial cues. Biofouling 12: 81-118.

http://dx.doi.org/10.1080/08927019809378348 